Paper to be presented at the $17^{\text {th }}$ EECERA Annual Conference

Prague, Czech Republic

$29^{\text {th }}$ August $-1^{\text {st }}$ September 2007

\title{
EARLY CHILDHOOD EDUCATION AND LEARNING FOR SUSTAINABLE DEVELOPMENT AND CITIZENSHIP
}

\author{
Solveig Hägglund Karlstad, University, Sweden \\ Ingrid Pramling Samuelsson Göteborg University, Sweden \\ Ingegerd Tallberg Broman Malmö University College, Sweden
}

\begin{abstract}
Since the end of the 1980:s when OECD published the Brundtland report, in which the concept of sustainable development as a critical global issue was introduced, the role of education for global survival has been frequently discussed and explored, by politicians as well as researchers. In the report, sustainable development is defined as "...development that meets the needs of the present without compromising the ability of future generations to meet their needs". In school curricula and practice, efforts have been made to include material and issues related to, for example, climate changes and nature resources in teaching and learning. Surprisingly little attention has however been paid to in what way and on what premises early childhood education may and should be involved. In our paper we will discuss some issues related to this. We will particularly bring forward and try to identify in what way preschool education can be seen as having a specific role in, and as carrying specific resources for, education for sustainable development. We will also discuss how the concept of learning in early education contexts can be related to sustainable development. As we see the concept of sustainable development as closely linked with citizenship, we will also consider this issue. Recent and on-going political transformations within the educational system in Sweden as well as planned and earlier research will serve as frames for our presentation.
\end{abstract}




\section{Introduction}

During the last decades media, politicians and research have directed increasingly and concerted attention towards issues of problems related to global survival. Included in this general phrasing we find a complex net of issues covering climate change and energy resources, as well as global justice and democracy. When OECD in the end of the 1980:s published the Brundtland report (ref) on sustainable development this was one of several manifestations of an increasing international awareness of the existence of a number of serious global problems that called for global policies and strategies. The UN and its suborganisations has played, and plays, a significant role in initiating and supporting several world meetings and summits connected with this theme. But also other actors, particularly NGO:s through their internationally framed community networks have been active in finding ways to formulate and conduct strategies for political, economical and cultural action to meet global threats to the survival of the planet and mankind.

Education plays an important role in this endeavour. A considerable amount of literature and documents have been produced on the role of education in finding ways to prepare citizens all over the world to act as to change the situation. However, surprisingly little attention has been paid to in what way and on what premises early childhood education (ECE) may and should be involved. In this paper we will bring light to and discuss some aspects of how ECE, as a particular part of the educational system, can be seen as having a specific role and as carrying specific resources in education for sustainable development. The thoughts and reflections being presented here, illustrate some of the bases that will direct the outline of a planned research project on early childhood education and sustainable development.

\section{Sustainable development, education and early childhood education}

In this section we will present a brief, introductory perspective on sustainable development and education. Our basic assumption is that neither sustainable development, nor education can be seen as only, or primarily, a national issue. Both concern social, cultural, environmental, economical and political courses of events with bearing on a global arena. This way of viewing goes well together with how the concept sustainable development has been presented. In the Brundtland-report, sustainable development is defined as "...development that meets the needs of the present without compromising the ability of future generations to meet their needs." (ref $\mathrm{p} \mathrm{xx}$ ). In the core ideas of the vision of a sustainable society we find that sustainability is looked upon as a dynamic rather than a static characteristic of a society, as a means rather than an end, as a challenge for continuous cultural and social change rather than a once and for all measurable outcome, and as challenging global solidarity and justice. Interestingly, there are large similarities between the way education for sustainable development is presented and literature on what have been referred to as peace education, education for democracy, values education, and citizen education (Hägglund, 1996, Hägglund, 1999; Hägglund \& Hill, 1999). Taken together, these areas for educational research and practice concern essential, normative aspects of education, which are linked with ideological and political systems directing educational policy and practice. This means that education for sustainable development not only is a matter of finding "subject-areas" in teaching, but that its mission is far-reaching, covering values related to democracy and solidarity. 
A quick glance at education and its global role in a historical perspective, tells us that education traditionally has been used as a tool for supporting the development of democracies, and for transformation of knowledge about health and technologies as well as of moral and religious values. To a large extent, these transformations have taken a nonquestioned north-to-south, industrialized-to-non-industrialized or "enlightened" -to-"non"enlightened" direction. This model of transformation of knowledge as a means to create a better world is now met by critical voices, arguing that there are reasons to re-define this onedirectional model as the model for successful education. There are at least two reasons for this model to be questioned.

The first reason is to be found in theoretical and empirical insights of the strong impact of contextual and situational dimensions in all kinds of learning. This has contributed to an understanding of education and transformation of knowledge rather as a socio-cultural project than a question of "exporting" knowledge from one culture to another (Vygotsky, 1986, Wertsch, xx ). A second reason concerns globalization and its implications. The extensive changes in social and cultural meanings of national borders, brought about by the shift from local to global economy, has revealed that other borders than the ones defined by nations are at work. When overpopulation, environmental damage, climate catastrophies, war and famine no longer are seen as caused by lack of knowledge among local populations, but linked to complex, global systems with extensive contributions from nations in the North Western hemisphere, then education as a solution to the problems face new dimensions (Lauder, 2006).

According to Lauder et al (2006) one such dimension has to do with the fact that modern educational systems are closely integrated with global economy, directing education towards needs being born within systems nourished by global market ideologies. Without going into this analysis any deeper, we can note that one fundamental issue raised by the authors is the question whether "...education is in some sense separate and removed from society so that it can act on it as an independent force for progress" (p. 61). Referring to the western education system and its role in social segregation, the authors conclude that the existence of inequality and lack of recognition of difference is a severe impediment to this, but that

"... inequality is not just a matter for education but for the structuring of the labour market and the welfare state, ... Without the appropriate economic and social conditions issues of social justice and democracy will not be settled. And, arguably, these are the necessary conditions for addressing the most fundamental problem of all, the sustainability of the planet" (Lauder et al, p 61-62).

In brief, the role of education in our time, a time characterized by, at the same time, globalization and individualization, has been described in terms of increasing integration with economic systems, thereby risking its independency and critical role in society. Also, according to Lauder et al, there are reasons to be worried concerning how education for citizenship is to be carried out within contemporary educational systems. According to these authors' reasoning, citizenship is one of the key issues in the world wide education today.

Although not specifically directed towards ECE, this very brief over-view of education in a global perspective indicates some, as we see it, fundamental issues that need to be considered in creating a relevant basis for researching early childhood education and sustainable development. At our preliminary, and so far rather sketchy, schedule for inquiry, we have defined three arenas for deeper search and questioning. These arenas are related to the preschool as an institution in the educational system, pedagogical practices in early childhood 
education, and the preschool child as a learner. Thus we notify the institutional question, the pedagogical question, and the question related to the child as citizen as necessary to pay attention to when defining the research landscape relevant for sustainable development and early childhood education. In the remaining part of this paper we will discuss these three aspects somewhat further.

\section{Preschool as an institution related to school and the life-long learning process}

A majority of Swedish children participate today in preschool from early year. Before the age of two $84 \%$ of all children attain preschool. In the Swedish educational policy, the preschool is seen as a part of the education system, expected to be the first step on a life-long learning process. A national curriculum directing the educational agenda, and a university based teacher training programme integrated with programmes for school teachers, are examples of changes that during the last decades have had impacts on the development of the Swedish preschool institution (SOU 1999:63). These changes can be traced to and are linked with Swedish family-, labour market-, and educational policies over the years (SOU 2000:3). In various ways the preschool has been used to strengthen political agendas in these areas rather than to support young children's learning. The overall object of preschool is however declared to be both to support the family and equality, and to support children.

In the first official National curriculum for the Swedish preschool (there were various forerunners to this, but this was the first formal curriculum) (Department of education and Sciences, 1998), sustainable development as such is not described as a particular goal. However, the formulations related to what in Sweden during the last decade has been referred to as basic values (värdegrund), make explicit values with bearing on sustainable development. Thus solidarity, tolerance, equality and justice belong to a battery of concepts which, according to us, are relevant in a wide definition of sustainable development. The national curriculum and the increasing focus on the academization of the pre-school teacher training was interpreted as expressions for a political emphasis on the role of pre-school as being a full-worthy member of the educational system. However, researchers have pointed at the fact that over time, relationships between institutions for early childhood education, other educational institutions, and society, tend to change. Vallberg Roth (2002) has shown how curricula for young children's education have shifted during history according to views of men and women, children and adults and the role of religion and society. For example, she suggests different kinds of curricula emphasising "time-typical" views of gender and authorities such as a curriculum of God, around 1850 to 1890 (with a patriarchal code), a curriculum of the Good Home, around 1890 to 1930/40 (a sex segregated code), a curriculum of the Welfare Sate, around 1950s to the middle of the 1980s (the gender-neutral equality code), and, finally, a curriculum of the Situated World Child, from the late 1980s up to today (the pluralistic, sex/gender code).

When it comes to a curriculum specifically directed towards ED, it seems as if such a curriculum is lacking not inly in Sweden but also in the rest of the world. ESD is hardly discussed as an object or as an act of learning (Pramling Samuelsson \& Asplund Carlsson, 2003). The object of learning, that is, what children are supposed to learn in preschool is defined in the Swedish curriculum as goals to strive for. This means that the direction of what the teachers are supposed to focus children's interest towards, rather than the exact content that children are supposed to learn. With reference to what we mentioned earlier, that it is 
possible to link values, as they are defined in the Swedish national curriculum for pre-school, to the definition of sustainable development, one may argue that this is an advantage for ESD since it is not a narrowly defined concept but rather should be looked upon as a vision or a perspective.

In Sweden today, there are signals indicating a political re-orientation for the status and position of pre-school in relation to the rest of the educational system. One line of change concerns an increasing number of institutions governed by other interests than communities. This goes for pre-schools as well as for compulsory and secondary schools. Critical voices have been raised warning for an increasing social and cultural segregation as a result. A second line of change concerns early indicators on changing policies for how the professional training of teacher in early childhood education should be organized. A shorter period of training and less integration with school-teachers to be, belongs to the scenario.

Taken together, in a preliminary outline for a research project on early childhood education and sustainable development, there are some issues worth closer attention. We have pointed at the importance of a curriculum as a tool for the organization and practice in preschool and we have highlighted changes in governing and teacher training as potentially having impacts on the role of pre-school as an instrument for social justice and equality. These are complex issues and we realize that what have been introduced here hardly can be seen as a complete picture. However, in the light of education for sustainable development, we find it important to consider the status of the pre-school institution in terms of an independent -and potentially critical- actor at the educational scene

\section{The pedagogy of preschool}

Preschool was developed on other grounds and merits than school, and is still run differently in most places in the world. The idea of young children's education in Sweden is in its origin strongly related to Fröbel and his view of making an education different from the school education (Fröbel, 1995). He had an idea about using the child's every day life as a frame of reference for their education, that is, all the activities done in a home, like kitchen work, sawing, working with wood work, gardening etc. This can be seen as a way of coming close to each child's experiences and what is known to them (Pramling Samulesson, Sommer \& Hundeide, manuscript). Learning should start from where the children are. He also knew that young children are different than older children and prescribed an approach in preschool based on play, learning and work. Young children have to be active in body and mind for being interested of what the teacher wants to teach children, and to get opportunities to learn. The idea of transforming knowledge to children, commonly practiced in school, has never been an alternative in preschool. Even though practice can have different qualities and give each child various experiences (Sheridan, manuscript) the discourse of preschool is as Wals (2006, p. 45) says:

So let us return to kindergarten and explore why kindergartens offer more for moving towards a more sustainable world than many of our universities. Kindergarten ideally is or can be places where young children live and learn, explore boundaries, in a safe and transparent world without hidden agendas. Kindergartens are places where conflicts emerge everyday and used as a 'teachable' moment. Kindergartens today are multi-cultural places where kids with different backgrounds all come together and get to know each other as they are, not as they are portrayed by others'. Kindergartens are places where different generations meet and interact (children, parents and grandparents). //.../ There are no dumb questions in kindergarten and there's always 
time for questions and questioning. The life-world of the child from the starting point for learning and not disciplinary problems. (ref xx p. xx)

The mission of preschool is different from school, emphasizing to educate the child as a whole individual, not only their minds. This implies that care and learning have to be integrated and of equal importance (Johansson \& Pramling Samuelsson, 2003). According to Halldén "The way childhood is shaped, says something about the society and its ways to distribute resources, rights and obligations." (Halldén, 2007, p.13) She argues for seeing children as agents but within a balance between the individual child and the childhoods they are involved in and argues for the importance of care, something that, according to her, easily can get lost in our ambitions to teach children. As we see it, care is an important aspect of all learning when it comes to young children. In the context of early childhood education and education for sustainable development it would be difficult not to include aspects of care as a necessary dimension in learning solidarity, democracy and rights (Hägglund, 2006). Research has shown that even though preschool children's lives in Sweden today can be described as highly institutionalized, pre-school offers a space for children's relationships within which moral and ethical aspect of relationships are elaborated and developed (Johansson, 2007). This is an important observation when discussing sustainable development as it has bearing on recognition of difference, a basic element in care and solidarity, both key concepts in sustainable development.

Research on pre-school children and learning has stated that children are playing learning individuals, and if education should learn from children an integration of play and learning into a wholeness would be on the agenda for a goal directed preschool.

Johansson and Pramling Samuelsson (2006, 2007) have studied teachers' possibilities to integrate the two, and found that there are certain criteria that have to be met. There must be an oscillation between fantasy and reality, the positions of the teacher and children have to be equal (both interested and curious), both teacher and children need to be actively involved and there should be a lot of space for children's initiatives and ideas. This also implies that the teacher sees the child as competent and willing to make sense. Somewhat different concepts are presented by Elkind (2007) who suggests play, work and love as the three criteria for a new model of ECE. As we understand it his concepts are similar to the ones above. Thus 'work' has similarities with 'learning', and 'love' corresponds to what Johansson and Pramling Samuelsson refer to as 'interactive and communicative relations between teachers and children'.

Teachers seem to experience dilemmas in preschool when they work more systematic and goal directed. For example they find themselves in the cross road between school and preschool, that is, to focus an object of learning (what) or focus the act (how) of learning. They also find themselves in the cross road between utilizing everyday routines or plan activities for children, or in the cross road between play and learning (Pramling \& Pramling Samuelsson, manuscript).

There is a lot of knowledge in the world that is unknown for the children. Working towards making the unknown visible to them means to create opportunities to discover the unknown in what they do and work with (Pramling Samuelsson, et al., manuscript). This puts demands on the teachers to be aware of what the child's learning should be directed towards (Pramling Samuelsson \& Asplund Carlsson, manuscript). On the other hand there are also an unknown future for the teachers, which of course is much more difficult to work towards. One way to deal with this might be to try to identify what all children may benefit from in the future. Johansson (2007) suggests that courage, integrity, critical thinking and responsibility are necessary for all children in order to be prepared for an unknown future. To be a citizen 
in a sustainable society requires the ability to recognize injustice, when human rights are violated, and the need of care.

A central question for the teachers working systematically with ESD is to have goals in terms of ideas of sustainable development in their minds, but at the same time be able to meet and challenge children's experiences and ideas (Pramling, 2005). But also the pedagogical approach is important. The approach must probably be open to variations and make the variation of children's ideas and experiences to a central task for fostering children' awareness of meaning making (Pramling, 1996). Individual involvement and responsibility are integral parts of the concept of sustainable development. These are aspects which preschool should have possibilities to work with since social development always have been and still is a key factor in young children's life. To help children develop responsibility successively should not be problematic at all. Individual involvement in preschool becomes a question of openness of the class room and the attitude of the teacher, but also the teacher's actual engagement in children's play and other activities. There is a rhetoric in preschool about children's play as the most important aspect, but still most teachers in the Wesern part of the world do not participate. It is however shown to be the opposite in China, where teachers always are engaged in children's play since they believe it is there they have the best opportunity to teach children the knowledge they want to mediate (Pramling Samuelsson \& Fleer, manuscript).

During an international workshop in Göteborg in May 2007 on the topic "The role of early childhood education for a sustainable society", recommendations for ESD and preschool children were formulated (Pramling Samuelsson \& Katz, manuscript). The above heart of preschool education, as theme oriented, authentic topics, close relations between teachers and children and between children, as well as the freedom to chose and learn to live in a democracy were all aspects that preschool are considered to be good at. The problems pointed at were defined as to be of a global kind, such as the fact that far from all children have access to a high quality preschool, educated teachers, and a safe and secure surrounding. When it comes to ESD, it was stated that even though children do have access to ECE, the teachers need to develop their own thinking, and to create their own ideas about ESD and what it means in everyday life with young children. In many Swedish preschools one is sorting and categorizing things for later re-cycling. But, it was argued, ESD is so much more than this. The key principle in ESD is that economic, social and environmental conditions and processes should be integrated into a whole, but also include opportunities to approach this whole from all different directions. It is here that the challenge for teachers comes in as they need to anchor the content to work on in preschool in terms of themes that bring all three aspects in to children's thinking, communication and acting. During the workshop some examples on how this could be done was presented. "The life in an egg", was the title of a presentation which ended up in a description of how to influence the municipality to buy egg from an eco-farm (Engdahl \& Ärlemalm-Hagsér, manuscript). Another presentation was about prawn cultivation, and dilemmas in a village to handle the question of employment on one hand and the bad smell of prawns on the other (Nordahl, manuscript). In both of these projects, all three dimensions were dealt with.

During the workshop it was also discussed the fact that there is a tendency among adults to think of the future as a catastrophe, and that this is something one should protect children from seeing. However, research shows that young children do develop ideas of abstract phenomena such as nation, enemy, war and peace (Hong-Ju, 2006, Hakvoort \& Hägglund, 2001)

In this section we have presented a brief and summarized overview of some aspects of the pedagogical practice in preschool, aspects that we see as important in the perspective of 
education for sustainable development. We have pointed at characteristic traits in the fundamental ideas of learning and teaching in the preschool tradition, such as the integration of playing and learning, care and learning and the necessary link between experience and learning. The new signals that we referred to in the former section are visible also here through a new dimension in the pedagogical practice. An increasing emphasis on a more goal directed education is observed. Since the challenge is to fulfill such a striving without linking it to school subjects in a traditional sense, the object of learning need to be discussed and questioned. As we see it, this is particularly important when talking about education for sustainable development.

\section{The child and the childhoods in focus for education for sustainable development}

The third arena that we find important in an outline for research on preschool and sustainable development concerns the preschool child and the preschool childhoods that are to be informed and involved in a global agenda on education for sustainable development. A clear common message in the perspectives and definitions gathered from different international contexts is that the time line for ESD encompasses several generations and that there is a global perspective. What does this mean in ECE? Does it mean that, from the perspective of the preschool child, concrete encounters with people representing other generations or other parts of the world are arranged? As we see it, this is not what it is about. Rather we interpret this in terms of infusing a perspective in education, unbounded by time and space. This means not only seeing each child's education in a long time perspective, but also an ambition to use content in the education that make children aware of time and history, as well as places and geography related, of course, to what is possible to grasp for a preschool child. As we see it, such an approach does not only make a relevant base in education for sustainable development, but it may also be seen as a step to create a sense of connection for the child. Such a sense of connection, of being part of something that stretches further than the own person, is as we see it, a necessary prerequisite in learning for sustainable development.

This way of looking at the child and her context may be a challenge to traditional models of child development. According to Lee (2005), the concept of separation as it has been used and understood in research on children and their development, needs to be closer examined and questioned. One of his arguments for this is that if parents and teachers are striving for the child to reach independency and ability to separate from other people, they may create an individual unable to connect and relate to other human beings. Instead of trying to foster the ability to separate fom others (i.e. to stress individualistic norms), he argues for 'separability', that is, an ability to both separate and connect in relation to other people. If this ability to meet other people as both dependent and independent is encouraged, the value of dependency and attachement is also recognized: "If all separateness rests on separability, then everyone, adult and child, no matter how effective their performance of separateness is in gathering value to themselves, is always attached, connected and dependent" (Lee 2005, p. 156).

Even if it is possible for teachers to create a sense of connectedness in preschool education, we know that in a global perspective, children in many parts of the world live in childhoods that are excluded from all kinds of education. We can easily refer to conditions for growing up in other parts of the world, where conflicts, poverty and famine make any attempt to organise education impossible. However, there are more close examples. When Sweden in its third report to the UN Committee for the Rights of the Child on strategies and activities to 
fulfil the intention of the Convention of the rights of the child, the committee criticized the way children who, together with their families, are waiting for a residence permit are being treated. Many of them are hidden from the authorities, but even if living openly in our society, these children's rights to education is not satisfactory met according to the committee.

When reflecting upon sustainable development, children and childhoods, an important part of the parcel concerns children's rights. According to the UN Convention on the Rights of the Child, each child, from the day s/he is born, carries human rights of the same dignity as those for an adult. Included in the rights as they are formulated in the 54 articles of the convention, is the right to have a say and to be heard in decisions that will have consequences for the child's situation. The question of sustainable development truly belongs to those issues that will have consequences for the life of next generation. Therefore it is logical to argue that children should be involved in these matters. However, such an ambition demands careful planning and reflection in order to meet the necessary balance between the child's right to be protected and to act independently. Alderson, in an article on children's rights and democracy in school contexts, argues that a critical issue is whether teachers and school leaders are successful in creating a climate of equality (Alderson, 1999). In preschools where social and cultural differences are exposed, ways of handling these differences may contribute to experiences of equality in practice. In segregated societies, and segregated schools and preschools, differences may be less visible and equality discursively rather than practically trained. Following this line of reasoning, socially and culturally segregated systems for ECE may offer other conditions for establishing processes of learning for sustainable development than those where differences are more visible. At least, this is one of the questions one should raise in a study of early childhood education and sustainable development.

When referring to the concept of 'childhood' as a social category (James et al 1998, James \& James, 2004) it reveals the fact that children belong to socially structured and constructed categories with particular relations to other social categories such as adults, men, immigrants, and working-class. When exploring ways of investigating conditions for education for sustainable development in early childhood, this implies that different social categories may have different experiences of phenomena with bearing on sustainable development. Material objects and nature resources, such as toys, cars or clean water may in some childhoods and for children belonging to them, be fantasy rather than reality, not only in a global perspective but also as a result of social and economical segregation at a local level.

Children have to work on what is close to them and what is here and now, but this does not mean that their attention cannot be directed towards a global society. Media and travelling contributes with more information about "the other" and other childhoods today than ever. The global society means that toys, clothes and food are produced all over the world, "the network society" affects not only adults but also children. Children quite early in life can see what is most appropriate in different situations and cultures (Siraj-Blachford, manuscript). This is the situation that form the challenge for ambitions to teach children about sustainable development and to give them inspiration and competence for citizenship, here and now and in the future. Ethical questions are as important as knowledge about environmental issues in this project.

\section{Concluding comment}

We have suggested that research on early childhood education and sustainable development need to consider at least three arenas for inquiry: the preschool as an educational institution 
and its relation to the educational system as well as to the society at large; the pedagogical practice in preschool, its traditions and challenges in terms of curricula and professional training; issues related to what child and what childhoods we have in mind when making education for sustainable development a reality. Far from a complete agenda for concrete research, this preliminary outline will serve as one step forward in the planning. Hopefully our sketchy notions have contributed to reflections and questions also among others, on young children and their role in the global work for sustainable development.

\section{References}

(NB - not complete)

Alderson, P. (1999). Human rights and democracy in schools, do they mean more than "picking up littter and not killing whales"? The International Journal of Children's Rights. 7: 185-205.

Björneloo, I. (2007). Innebörder av hållbar utveckling. En studie av läraraes utsagor om undervisning. Göteborg: Acta Universitatis Gothoburgensis. Diss.

Davies, L. (2004). Education and conflict. Complexity and chaos. London: Routledge Falmer.

Ekborg, M. (2002). Naturvetenskaplig utbildning för hållbar utveckling? En longitudinell tudie a hur studenter på grundskollärarprogrammet utvecklar för miljöundervisning relevana kunskaper i naturkunskap. Göteborg. Acta Universitatis Gothoburgensis. Diss.

Elkind, D. (2007). The power of play. Cambridge: Da Capo Lifelong Books.,

Engdahl, I, \& Ärlemalm-Hagsér, E. (manuscript). Swedish preschool children show interest and are involved in the furure world. In Pramling Samulesson \& L. Katz, (Eds). The comtributions of early childhood education for a sustainable society. UNESCO report.

Fröbel, F. (1995). Människans fostran. Lund: Studentlitteratur

Hakvoort, I. \& Hägglund, S. (2001) Peace and war described by seven-to-seventeen-year-old Dutch and Swedish girls and boys. Peace and Conflict. Journal of Peace Psychology. , 7 (1), 29-44.

Halldén, G. (2007). Den moderna barndomen och barns vardagsliv. Stockholm: Carlssons.

Hong-Ju. (2006). Teaching and Learning about the Concept of "nation" in Preschool Classroom. International Journal of Early Childhood Education, The Korean Society for Early Childhood Education, 12, 2, p 129-150.

Hägglund, S. (1996). Developing concepts of peace and war: Aspects of gender and culture. The Peabody Journal of Education, (71) 3, pp 29-41.

Hägglund, S. (1999). Peer-relationships and children's understanding of peace: A sociocultural perspective. In A. Raviv, L. Oppenheimer \& D. Bar-Tal (Eds). Children's and adolescents' understanding of war, conflict and peace: International perspectives . San Francisco: Jossey Bass. Pp. 190-208.

Hägglund, S. (2006). Det hela barnet -vem är det? Reflektioner kring några texter av Nel Noddings. Utbildning \& Demokrati, 15 (1), 43-60.

Hägglund, S. \& Hill, M. (1999) Education for democracy in a European context. In A. Perucca \& J. Calleja (eds). Peace education, context and values. Lecce: Pensa Multimedia Lecce. 111-135. 
James, A., Jeks, C., Prout, A. (1998). Theorizing childhood. Cambridge: Cambridge Polity Press.

James, A. \& James, A. L. (2004). Constructing childhood: Theory, policy and social practice. New York: Palgrave MacMillan.

Johansson, E. \& I. Pramling Samuelsson (2001). "Omsorg - en central aspekt av förskolepedagogiken. Exemplet måltiden." Pedagogisk Forskning i Sverige 6 (2): 81101 .

Johansson, E. \& I. Pramling Samuelsson (2006). Lek och läroplan. Möten mellan barn och lärare i förskola och skola. Göteborg: Acta Universitatis Gothoburgensis.

Johansson, E. (2007). Etiska möten i förskolebarns världar. Acta universitatis

Gothoburgensis. Göteborg Studies in Educational Sciences 251. Göteborg:

Göteborgs universitet.

Johansson, E. \& Pramling Samuelsson, I. (2007). Att lära är nästan som att leka. Stockholm: Liber.

Lauder, H., Brown, P., Dillabough, J.-A., Halsey, A. H. (2006). Introduction: The prospects for education. Individualization, globalization and social change. In H. Lauder, P. Brown, J.-A. Dillabough, A. H. Halsey: Education, globalization and social change. Oxford: University Press. Pp. 1-70.

Lee, N. (2005). Childhood and human value. Development, separation and separability. London: Open University Press.

Ministry of Education and Sciences (2004). Learning to change our world. International consultation on education for sustainable development.

Nordahl, K. (manuscript). What might Early Childhood Education for sustainability look like? In Pramling Samulesson \& L. Katz, (Eds). The comtributions of early childhood education for a sustainable society. The comtributions of early childhood education for a sustainable society. UNESCO report.

OECD The Brundtland report-REF!

Pramling, I. (1996). Understanding and Empowering the Child as a Learner. In D. Olson and N. Torrance. (Eds). Handbook of Education and Human Development: New Models of learning, teaching and schooling. Oxford, Basil Blackwell: 565-592.

Pramling Samuelsson, I. (2005). "Can play and learning be integrated in a goal-orientated preschool?" Early Childhood Practice: The Journal for Multi-Professional Partnerships. Spring. www.earlychildhoodpractice.net 7(1).

Pramling Samuelsson, I., Katz L. (2007) (Eds). The contribution of early childhood education for a sustainable society. UNESCO report no X.

Pramling Samuelsson, I., Hundeide, K. \& Sommer, D. (manuscript) Chid perspectives and children's perspectives in theory and practice.

Pramling Samuelsson, I. \& Asplund Carlsson, M. (2003). Det lekande lärande barnet. I en utvecklingspedaogisk teori. Stockholm: Liber. 
Pramling Samuelsson, I \& Asplund Carlsson, M. (manuscript). The Playing Leanring Child. Towards a Pedagogy of Early Childhood. Acceted for pubication in Scandinavian Journal of Education.

Pramling Samuelsson, I. \& Fleer, M. (manuscript). Play and learning in Early Childhood Settings: International perspectives. New York: Springer Verlag.

Pramling Samuelsson, I., Asplund-Carlsson, M., Olsson, B., Pramling, N. \& Wallerstedt, C. (manuscript) Konsten att lära barn estetik.

Pramling, N. \& Pramling Samuelsson, I. (manuscript). Lärstudier i förskolans kontext.

Siraj-Blachford, J. (manuscript). The implications of early understanding of inequality, science and technology for the development of sustainable societies. In Pramling Samulesson \& L. Katz, (Eds). The comtributions of early childhood education for a sustainable society. The comtributions of early childhood education for a sustainable society. UNESCO report.

Sheridan, S. (manuscript). Barns tidiga lärande. En longitudinell studie om kavlitet och barns lärande i förskolan.

SOU (1999:63). Att lära och leda. En lärarutbildning för samverkan och utveckling.

Lärarutbildningskommitténs slutbetänkande. Stockholm, Utbildningsdepartementet.

SOU (2000:3). Välfärd vid vägskäl. Utveckling under 1990-talet. Delbetänkande. Kommittén Välfärdsbokslut. Stockholm, Fritzes.

Vygotsky, L. (1986) Thought and language. Boston, MA: MIT Press

Wals, A. (2006). The end of ESD... the beginning of transformative learning - emphasizng the E in ESD. Paper presented at the Gotenburg Consultation on Susatinability in Higher Education, December.

Wickenberg, P., Axelsson, H., Fritzén, L., Helldén, G., Ödman, J. (2004). Learning to change our world? Swedish research on education and sustainable development. Lund: Studentlitteratur.

Vallberg Roth, A-C. (2003) De yngre barnens läroplanshistoria. Lund: Studentlitteratur. 